\title{
Immunogenicity of Pfizer mRNA COVID-19 vaccination followed by J\&J adenovirus COVID-19 vaccination in two CLL patients
}

3

Zoe L. Lyski, ${ }^{1}$ Sunny Kim, ${ }^{2}$ David Xthona Lee, ${ }^{1}$ David Sampson, ${ }^{2}$ Hans P. Raué, ${ }^{4}$

Vikram Raghunathan, ${ }^{2}$ Debbie Ryan, ${ }^{2}$ Amanda E. Brunton, ${ }^{3}$ Mark K. Slifka, ${ }^{4}$ William B. Messer, ${ }^{1,3,5}$ Stephen E. Spurgeon. ${ }^{2 *}$

\section{Affiliations}

1. Department of Molecular Microbiology \& Immunology, Oregon Health \& Science University (OHSU), Portland, OR 97239, USA.

2. Knight Cancer Institute, Oregon Health \& Science University (OHSU), Portland, OR 97239, USA

3. OHSU-PSU School of Public Health, Portland, OR 97239, USA.

4. Division of Neuroscience, Oregon National Primate Research Center, Oregon Health \& Science University, Beaverton, Oregon, USA.

5. Department of Medicine, Division of Infectious Diseases, Oregon Health \& Science University (OHSU), Portland, OR 97239, USA.

*Corresponding author: Knight Cancer Institute OHSU, 3303 S. Bond Avenue, Portland, Oregon 97239. Phone: (503) 494-5058. Email: spurgeos@ohsu.edu

Funding: This work was funded in part by National Institute of Allergy and Infectious Diseases NIAID 1R01AI145835 (WBM), by US National Institute of Health grant P51 OD011092 (MKS), and endowed funds from the Knight Cancer Institute's Scholar Award for Leukemia and Lymphoma Research (SES).

Conflict of interest statement (SES): Consulting: Velos Bio, Karyopharm, Genentech; Janssen, Pharmacyclics; Research: Acerta Pharma, Astrazeneca, Beigene, Bristol Myers Squibb, Genentech, Gilead Sciences, Ionis, Janssen

All other authors, have no conflict of interest. 
Chronic Lymphocytic Leukemia (CLL) is characterized by monoclonal proliferation of

42 disease status, baseline characteristics, types of vaccine and active CLL therapy (3).

43 Although current COVID-19 vaccines elicit robust immunity in immunocompetent hosts (4), the

44 antibody response in CLL patients is highly variable $(5,6)$ and particularly poor in patients with

45 low total immunoglobulin levels, those that have had anti-CD20 monoclonal antibodies within

46 the past year, or are undergoing active therapy with agents such as Bruton's Tyrosine Kinase

47 inhibitors (BTKi). The best responses to date have been in CLL patients who are in remission and/or years out from active treatment.

49 Given decreased vaccine efficacy in CLL, an additional dose of vaccine may be beneficial in

50 CLL patients, especially given rise of variants of concern (VoCs). Initial data from solid organ

51 transplant recipients on immunosuppression showed a role for additional vaccination (7), leading

52 the FDA to extend the EUA for Pfizer-BioNTech and Moderna mRNA vaccines to include

53 additional doses in immunocompromised patients. However, the results in solid organ transplant

54 patients may not be generalizable to CLL, and additional studies are needed to better define

55 vaccine responses in the CLL patient population, including the role of mixing mRNA

56 vaccination with other vaccine formulations, such as the adenovirus vectored vaccine

57 Ad26COV2.s, commonly known as Johnson and Johnson (J\&J) vaccine.

58 Here we describe two CLL patients who "self-referred" to outside pharmacies for an additional

59 vaccination with J\&J COVID-19 vaccine following 2 doses of the BNT162b2 vaccine (Pfizer- 
BioNTech). Both patients had previously enrolled as study subjects in an IRB approved

61 observational study, (OHSU IRB\# 21230) to investigate immune response following COVID-19

62 vaccination. The additional J\&J dose was subsequently self-reported to the study team. On

63 initial enrollment, demographics, CLL disease characteristics, and treatment details were

64 collected (Table 1), and baseline laboratory values were obtained, included semi-quantitative

65 SARS-CoV-2 spike antibody titer, serum IgG, a complete blood count, and multicolor flow

66 cytometry measuring immune cell populations (Table 1). Whole blood was collected for

67 additional serologic and cellular studies.

68 SARS-CoV-2 spike receptor binding domain (RBD)-specific antibody levels were tested by

69 ELISA and endpoint titers were calculated as previously described (8). In addition, baseline

70 PBMC samples were functionally tested for the presence of SARS-CoV-2 spike RBD-specific

71 memory B-cells (MBCs) by limiting dilution assay $(9,10)$ and CD4+ and CD8+ T-cells were

72 functionally assessed for the presence of IFN $\gamma$ and $\mathrm{TNF} \alpha$ secretion following spike protein

73 derived peptide stimulation.

74 Neither subject had pre-vaccination B-cell responses as measured by RBD-specific antibodies or

75 MBCs. Neither had a virus-specific CD8+ response at baseline. While Subject 2 had spike

76 peptide-reactive CD4+ T-cells at baseline these cells were unresponsive and did not expand

77 following vaccination. In contrast, CD8+ responses were observed after mRNA vaccination in

78 both subjects (Fig. 1). It has previously been reported that SARS-CoV-2 naïve individuals may

79 have preexisting cross-reactivity to SARS-COV-2 peptides through prior infection by common

80 cold coronaviruses: SARS-CoV-2 specific CD4+ T-cells have been identified in 20-50\% of

81 people without SARS-CoV-2 exposure or vaccination (11). 
82 Approximately four weeks after initial vaccination neither subject had detectable RBD-specific

83 SARS-CoV-2 antibodies or MBCs. Both had measurable vaccine-induced CD8+ T-cell

84 responses following mRNA vaccination, although CD4+ responses did not appear to increase

85 above baseline (Fig. 1).

86 Subject 1 received the J\&J vaccine 104 days and Subject 2- 81 days after completion of the

87 BNT162b2 vaccine series. Following J\&J vaccination additional samples were obtained, Subject

88 1, 30 days after third vaccine, and Subject 2, 27 days following third vaccine. Interestingly,

89 Subject 1 had undetectable RBD-specific antibodies, RBD-specific MBCs, and virus-specific

90 CD4+ T-cells after initial vaccination series. However, following an additional vaccination, all

91 three measures increased above the limit of detection, RBD ELISA titer of 625, RBD-specific

$92 \mathrm{MBC}$ frequency of 3.6 / $10^{6} \mathrm{~B}$-cells, and 166 spike-specific CD4+ T-cells / $10^{6}$, and a spike-

93 specific CD8+ T-cell response that remained stable and did not boost appreciably following $3^{\text {rd }}$

94 vaccination (Fig. 1). Subject 2 did not seroconvert or have detectable virus specific MBCs after

95 their primary mRNA vaccination series however they had a spike-specific CD8+ T-cell response

96 that further boosted after a $3^{\text {rd }}$ dose and a virus-specific CD4+ response that didn't change

97 following original vaccine series or $3^{\text {rd }}$ dose of J\&J.

98 Other than subject age (60s vs 80 s), the most notable difference between the subjects' baseline

99 characteristics (table 1) is that Subject 1 was treatment naive, while Subject 2 had undergone

100 previous treatment (6 years ago) with obinutuzumab an anti-CD20 mAb and is currently on

101 active treatment with Ibrutinib, since 2017. Both had baseline B-cell frequencies outside of the

102 normal range, with Subject 1 exhibiting a low percentage of naïve B-cells (0.092) and a high

103 percentage of MBCs (59.1), while Subject 2 had a low percentage of naïve B-cells (11.37) and

104 MBCs (0.45). Although Subject 2 had mild hypogammaglobulinemia, neither had a history of 
105 recurring infections or need for IgG supplementation. Levels of baseline CD4+ and CD8+ T-

106 cells (absolute values) were also normal, in each subject prior to vaccination (data not shown).

107 Both had very low percentages of naïve B cells which could explain the initial poor response to

108 vaccination. The significance of the increased percentage of MBCs in Subject 1 is unclear but

109 does suggest some broader preservation of normal B cell maturation and immune function.

110 Although Subject 1 did have an immune response, antibody levels were relatively low as

111 compared to some of the levels observed in immunocompetent post-vaccine populations (12) and

112 certain CLL populations (5). The clinical significance of specific antibody levels remains

113 unknown.

114 Active treatment with Bruton's Tyrosine Kinase (BTK) inhibitors like ibrutinib may have a

115 profound impact on B-cell survival, differentiation, and production of antibodies as the absence

116 of intact BTK-dependent B-cell receptor mediated signaling prevents B-cells from

117 differentiating into mature peripheral B-cells. Immune response following vaccination or natural

118 infection is limited in these patients (13). Recall to antigens encountered prior to treatment

119 appears to remain largely intact, however response to novel antigens encountered during

120 treatment seems to be abrogated. Subject 2 has been on ibrutinib for over four years. The impact

121 of prolonged treatment vs. shorter-term BTK inhibition on immune responses is unknown.

122 However, clinical data (14) suggest some improvement in humoral immunity with prolonged (>

1236 months) treatment. T-cells are also disrupted in individuals with CLL and even further

124 disrupted with BTK treatment (15). In the cases presented here both subjects did have an

125 increase in virus specific CD8+ T-cells however the significance is unclear in terms of protection

126 as neutralizing antibodies are often viewed as the correlate of protection against COVID-19. 
medRxiv preprint doi: https://doi.org/10.1101/2021.09.02.21262146; this version posted September 7, 2021. The copyright holder for this preprint

(which was not certified by peer review) is the author/funder, who has granted medRxiv a license to display the preprint in perpetuity.

It is made available under a CC-BY-ND 4.0 International license.

127 The results of this study, however small, provide initial evidence that a $3^{\text {rd }}$ vaccination against

128 COVID-19 with the heterotypic vaccine Ad26COV2.s results in an immune response that was

129 not observed following the recommended 2-dose mRNA vaccination series. This is especially

130 promising news to subjects who are treatment naïve, not currently in active treatment, or who

131 may consider vaccination before beginning active treatment.

132

133 Acknowledgements

134 The authors would like to thank the subjects for participating in this research study.

135

136

137

138

139

140

141

142

143

144

145

146

147

148

149 


\section{References}

153 1. Wadhwa P, Morrison V. Infectious Complications of Chronic Lymphocytic Leukemia. Seminars in

154 Oncology. 2006;33(2):240-9.

155 2. Scarfò L, Chatzikonstantinou T, Rigolin GM, Quaresmini G, Motta M, Vitale C, et al. COVID-19

156 severity and mortality in patients with chronic lymphocytic leukemia: a joint study by ERIC, the European

157 Research Initiative on CLL, and CLL Campus. Leukemia. 2020;34(9):2354-63.

158 3. Whitaker JA, Parikh SA, Shanafelt TD, Kay NE, Kennedy RB, Grill DE, et al. The humoral immune 159 response to high-dose influenza vaccine in persons with monoclonal B-cell lymphocytosis (MBL) and 160 chronic lymphocytic leukemia (CLL). Vaccine. 2021;39(7):1122-30.

161 4. Polack FP, Thomas SJ, Kitchin N, Absalon J, Gurtman A, Lockhart S, et al. Safety and Efficacy of 162 the BNT162b2 mRNA Covid-19 Vaccine. New England Journal of Medicine. 2020;383(27):2603-15.

163 5. Herishanu Y, Avivi I, Aharon A, Shefer G, Levi S, Bronstein Y, et al. Efficacy of the BNT162b2

164 mRNA COVID-19 vaccine in patients with chronic lymphocytic leukemia. Blood. 2021;137(23):3165-73.

165 6. Roeker LE, Knorr DA, Thompson MC, Nivar M, Lebowitz S, Peters N, et al. COVID-19 vaccine 166 efficacy in patients with chronic lymphocytic leukemia. Leukemia. 2021.

167 7. Kamar N, Abravanel F, Marion O, Couat C, Izopet J, Del Bello A. Three Doses of an mRNA Covid16819 Vaccine in Solid-Organ Transplant Recipients. New England Journal of Medicine. 2021;385(7):661-2.

169 8. Thomas A, Messer WB, Hansel DE, Streblow DN, Kazmierczak SC, Lyski ZL, et al. Establishment of 170 Monoclonal Antibody Standards for Quantitative Serological Diagnosis of SARS-CoV-2 in Low-Incidence 171 Settings. Open Forum Infectious Diseases. 2021;8(3).

172 9. Lyski ZL, Brunton AE, Strnad MI, Sullivan PE, Siegel SAR, Tafesse FG, et al. SARS-CoV-2 specific 173 memory B-cells from individuals with diverse disease severities recognize SARS-CoV-2 variants of 174 concern. medRxiv. 2021:2021.05.28.21258025. 
medRxiv preprint doi: https://doi.org/10.1101/2021.09.02.21262146; this version posted September 7, 2021. The copyright holder for this preprint (which was not certified by peer review) is the author/funder, who has granted medRxiv a license to display the preprint in perpetuity.

It is made available under a CC-BY-ND 4.0 International license .

175 10. Amanna IJ, Slifka MK. Quantitation of rare memory B cell populations by two independent and

176 complementary approaches. Journal of Immunological Methods. 2006;317(1-2):175-85.

177 11. Mateus J, Grifoni A, Tarke A, Sidney J, Ramirez SI, Dan JM, et al. Selective and cross-reactive

178 SARS-CoV-2 T cell epitopes in unexposed humans. Science. 2020;370(6512):89-94.

179 12. Bates TA, Leier HC, Lyski ZL, Goodman JR, Curlin ME, Messer WB, et al. Age-Dependent

180 Neutralization of SARS-CoV-2 and P.1 Variant by Vaccine Immune Serum Samples. JAMA. 2021.

181 13. Pleyer C, Ali MA, Cohen JI, Tian X, Soto S, Ahn IE, et al. Effect of Bruton tyrosine kinase inhibitor

182 on efficacy of adjuvanted recombinant hepatitis B and zoster vaccines. Blood. 2021;137(2):185-9.

183 14. Sun C, Tian X, Lee YS, Gunti S, Lipsky A, Herman SEM, et al. Partial reconstitution of humoral

184 immunity and fewer infections in patients with chronic lymphocytic leukemia treated with ibrutinib.

185 Blood. 2015;126(19):2213-9.

186 15. Roessner PM, Seiffert M. T-cells in chronic lymphocytic leukemia: Guardians or drivers of

187 disease? Leukemia. 2020;34(8):2012-24.

188

189

190

191

192

193

194

195

196

197 


\section{$200 \quad$ Figure legends}

201 Table 1. Baseline Characteristics and demographics for subjects included in the study. Normal

202 ranges for each of the B-cell subset are in parenthesis under each B-cell type.

204 Figure 1. Immune response to COVID-19 vaccination in CLL subjects. RBD-specific antibody

205 (Ab) titer. Subjects without a detectable $\mathrm{Ab}$ titer $(<1: 50$ serum dilution) were assigned a value of

206 49. Frequency of RBD- specific MBCs per $10^{6}$ CD19+ B-cells following ex vivo stimulation.

207 Subjects who did not have a detectable response were assigned a value of 5X10 ${ }^{-6}$. SARS-CoV-2

208 spike peptide-reactive CD4 and CD8 T-cells are defined as double positive for IFN $\gamma$ and TNF $\alpha$

209 cytokine secretion. Patients who did not have a detectable T-cell response were assigned an

210 arbitrary number between less than 2. Visit 1 (pre) blood draw was taken 21 and 40 days prior

211 Pfizer vaccine series (2-doses). Visit 2 (V2) blood draw was taken 33 and 24 days post

212 vaccination, and visit 3 (V3) was drawn 30 and 27 days after 3rd vaccination with J\&J. 
medRxiv preprint doi: https://doi.org/10.1101/2021.09.02.21262146; this version posted September 7, 2021. The copyright holder for this preprint

(which was not certified by peer review) is the author/funder, who has granted medRxiv a license to display the preprint in perpetuity.

It is made available under a CC-BY-ND 4.0 International license .

Table 1.

\begin{tabular}{|c|c|c|c|c|c|c|c|c|c|c|c|}
\hline $\begin{array}{l}\text { Subject } \\
\text { ID }\end{array}$ & Age & Gender & $\begin{array}{c}\text { Year of } \\
\text { Diagnosis }\end{array}$ & $\begin{array}{c}\text { Current } \\
\text { Treatment }\end{array}$ & $\begin{array}{c}\text { Prior } \\
\text { Treatment }\end{array}$ & $\begin{array}{c}\mathrm{lgG} \mathrm{mg} / \mathrm{dL} \\
(768-1632) \\
\end{array}$ & $\begin{array}{c}\text { Absolute Lymphocyte } \\
\text { Count K/mm3 } \\
(1.00-4.80) \\
\end{array}$ & $\begin{array}{c}\text { B-cells } \\
(C D 19+) \% \\
(4-17) \\
\end{array}$ & $\begin{array}{c}\text { Naïve B-cells } \\
(\text { laD+CD27-) \% } \\
(50-80) \\
\end{array}$ & $\begin{array}{c}\text { Memory B-cells (IgD- } \\
\text { CD27+) \% } \\
(5-21) \\
\end{array}$ & $\begin{array}{c}\text { B1 B-cells } \\
(\text { CD5+CD19+) \% } \\
(<6) \\
\end{array}$ \\
\hline 1 & 60's & $\mathrm{F}$ & 2014 & None & None & 834 & 21.09 & 76 & 0.092 & 59.1 & 76.18 \\
\hline 2 & 80 's & $\mathrm{F}$ & 2014 & Ibrutinib & Obinutuzumab & 510 & 5.93 & 61 & 11.37 & 0.45 & 59.96 \\
\hline
\end{tabular}




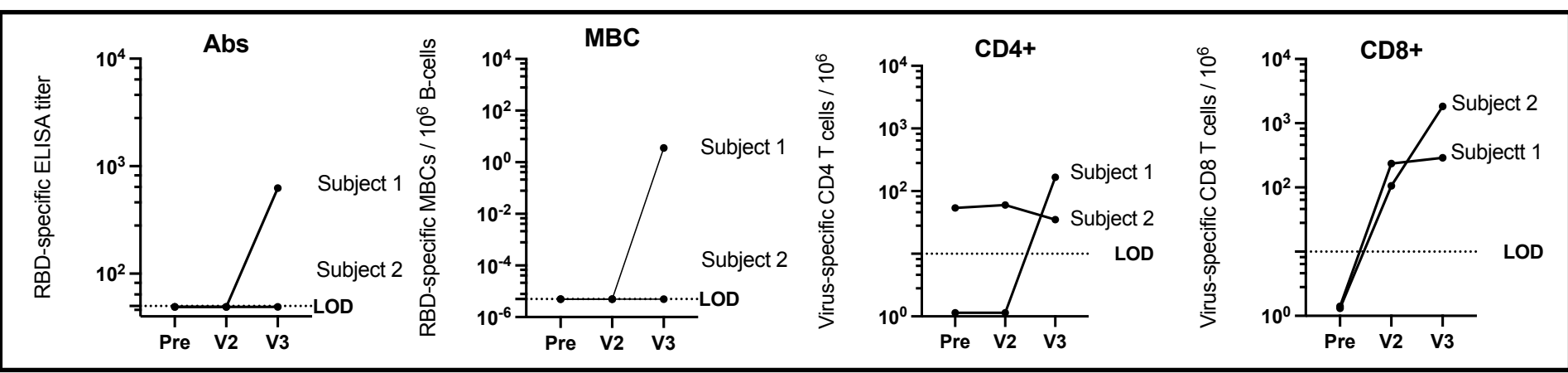

Fig. 1 Immune response to COVID-19 vaccination in CLL subjects. RBD-specific antibody (Ab)

titer. Subjects without a detectable Ab titer (< 1:50 serum dilution) were assigned a value of 49 .

Frequency of RBD- specific MBCs per $10^{6}$ CD19+ B-cells following ex vivo stimulation. Subjects who did not have a detectable response were assigned a value of $5 \times 10^{-6}$. SARS-CoV-2 spike peptide-reactive CD4 and CD8 T-cells are defined as double positive for IFN $\gamma$ and TNF $\alpha$ cytokine secretion. Patients who did not have a detectable T-cell response were assigned an arbitrary number between less than 2 . Visit 1 (pre) blood draw was taken 21 and 40 days prior to Pfizer vaccine series (2-doses). Visit 2 (V2) blood draw was taken 33 and 24 days postvaccination, and visit 3 (V3) was drawn 30 and 27 days after 3rd vaccination with J\&J. 